\title{
Article \\ EmDigital to Promote Digital Entrepreneurship: The Relation with Open Innovation
}

\author{
Paz Prendes-Espinosa * (D), Isabel María Solano-Fernández $(\mathbb{D}$ and Pedro Antonio García-Tudela \\ Department of Didactic and School Organization, University of Murcia, 30100 Murcia, Spain; \\ imsolano@um.es (I.M.S.-F.); pedroantonio.garcia4@um.es (P.A.G.-T.) \\ * Correspondence: pazprend@um.es
}

Citation: Prendes-Espinosa, P.;

Solano-Fernández, I.M.;

García-Tudela, P.A. EmDigital to

Promote Digital Entrepreneurship:

The Relation with Open Innovation. J.

Open Innov. Technol. Mark. Complex.

2021, 7, 63. https://doi.org/

10.3390/joitmc7010063

Received: 19 January 2021

Accepted: 9 February 2021

Published: 17 February 2021

Publisher's Note: MDPI stays neutral with regard to jurisdictional claims in published maps and institutional affiliations.

Copyright: (c) 2021 by the authors. Licensee MDPI, Basel, Switzerland. This article is an open access article distributed under the terms and conditions of the Creative Commons Attribution (CC BY) license (https:// creativecommons.org/licenses/by/ $4.0 /)$.

\begin{abstract}
Entrepreneurial skills and digital competence are two basic competences in people's education in the 21st century. They are also transversal competences in university degrees. We carried out an analysis of European models, which suggest areas and indicators within these two competencies (entrepreneurial and digital), with the ultimate goal of elaborating an original model of digital entrepreneurship competence, which we have named EmDigital. This analysis was performed by means of a qualitative approach and the combination of documentary analysis techniques, focusgroup discussion and expert judgement through the Delphi method in a sequence of four consecutive phases. The proposed EmDigital model encompasses 4 areas, 15 sub-competences and 45 indicators. This model will be useful for the design of descriptive types of tests and certification tests, as well as for the design of formative proposals both for professors and for students of higher studies. Furthermore, the model will lead to new lines of research in the area of competence-based training.
\end{abstract}

Keywords: digital entrepreneurship; competences model; higher education; EntreComp; DigComp; qualitative research

\section{Introduction}

Even though entrepreneurship has been traditionally associated with the economic and business field, it is currently considered one of the main objectives to ensure the social, cultural and economic development of any region [1,2], and, as a consequence, it is considered a basic competence in any citizen's training [3-5] and a personal commitment to improve our everyday environment [6].

Entrepreneurship, in its broader sense, is related to the idea of progress of any society. For this reason, entrepreneurship, throughout history, has always been linked to innovation $[7,8]$, since by means of innovation, processes of change and improvement from an original idea are promoted. Today, ICTs are deemed a necessary instrument to promote innovation, and the digital world is an optimal context to create value and maintain up-to-date proposals, although they inevitably lead to many raised questions.

In order to tackle the challenge of innovation in the digital scope, different social agents agree that training in both entrepreneurship competence [9] as well as digital competence $[10,11]$ is key. We have focused our research on both competences to design an innovative model of digital entrepreneurship (EmDigital), as we explain in this article.

\section{Literature Review: Entrepreneurial and Digital Competences}

In regard to entrepreneurial competence, in the European model EntreComp [2,5], entrepreneurship is defined as the capacity of turning the opportunities and ideas to develop new possibilities into actions in social, cultural or financial environments. This model was designed on behalf of the European Commission as a tool to analyze the entrepreneurial guidance of the training plans in the countries that make up the EU. Reference [12] (p. 8) defines entrepreneurship competence as "an individual's ability to 
turn ideas into action. It includes creativity, innovation and risk-taking, as well as the ability to plan and manage projects in order to achieve objectives. This supports individuals, not only in their everyday lives at home and in society, but also in the workplace [ ... ]. This should include awareness of ethical values and promote good governance".

Along with entrepreneurial competence, some authors [12] considered digital competence as one of the key competences in continuous training. Rather than the different models of digital competence in $[13,14]$, we chose to revise the European framework: the DigComp model. The model has been completed in further works, where the areas and sub-competences have been specified and outlined $[15,16]$, and, in addition, the models DigCompEdu, on teachers' digital competence, and DigCompOrg, on digitally competent organizations, have been developed. The definition of digital competence that these models use as a starting point lays bare, not unlike the abovementioned entrepreneurship competence, the intricate framework of dimensions and its applicability in all environments, both personal and social as well as in the workplace. The definition is ([12] p. 6): "involves the confident and critical use of Information Society Technology (IST) for work, leisure and communication. It is underpinned by basic skills in ICT: the use of computers to retrieve, assess, store, produce, present and exchange information, and to communicate and participate in collaborative networks via the Internet".

Focusing on higher education, we observe that both competences have been regarded as general or transversal in syllabuses/study plans and that there are several interesting experiences of analysis as well as training, self-perception and evaluation. Regarding entrepreneurship, Reference [17] features the analysis of an experience based on an entrepreneurship competition in higher education. According to the participants, the development of certain soft skills related to entrepreneurship competence can compensate for the low or even non-existent professional experience that third grade students usually possess, which makes this proposal an enriching experience for all students irrespective of their field of expertise. Reference [18] utilized a platform to promote education for entrepreneurship following the EntreCom4LL model, linking entrepreneurship to sustainable development objectives.

However, on the whole, it can be observed that the use of the EntreComp model has been scarce and its impact low so far, according to empirical and theoretical works [19]. The authors of [20] echo this outlook, evidencing that entrepreneurship competence is not sufficiently integrated in university study plans, to the extent that in certain university degrees - for instance, education - professors do not consider said competence for their students' professional career prospects. Similarly, Reference [9] shows that students' selfperception still scores low in this competence. In turn, the authors of [21] express the need to establish a common framework of education for entrepreneurship, adaptable to all degrees.

On the other hand, digital competence poses a great challenge for teachers, as they need to reformulate their practice to become digitally competent professionals [14,22], which directly influences their students' training. Provided technology is integrated in the curriculum, and the student will develop their digital competence while simultaneously addressing the contents of a specific subject, optimizing in this manner the training process [23].

If we analyze the work carried out in education on digital competence, we find several successful experiences in university students' training [24-27]. Other authors focus on teachers' digital competence [14,28,29]. More recently, Reference [11] proposed an integral model, which is used to analyze the competences in both educational agents-students and professors-in the scope of the organization, following the DigCompOrg model on digitally competent organizations.

The goal of our work was not that of addressing the two mentioned competences independently but carrying out an analysis of interrelations that enables us to draft a model of analysis of a new, different competence: digital entrepreneurship competence. Digital entrepreneurship consists of the development of an innovative business concept exclusively by means of digital means and making use of the virtual world [30,31]. Reference [32] 
assumes that digital entrepreneurship implies changes in at least three aspects: reducing barriers when starting a new business, creating new opportunities for entrepreneurial activity and posing new challenges for new businesses which have not existed before. Especially interesting is the contribution made by the authors of [33], who state that digital entrepreneurs are not concerned with technology itself but centered on the service that these technologies provide.

This new form of entrepreneurship is deemed of great interest for university students [34]. On the same subject, the authors of [35] consider this a valuable opportunity for students, due to the minimal initial investments that need to be made to create a start-up, not to mention the alternative means of collective funding, such as crowdfunding, which are also available. Moreover, through this type of digital initiative, young entrepreneurs usually count on an added value, internationalization, as they can explore the gateway to a global market in a more effective way [36]. The synergy generated between entrepreneurship and technology is responsible for a new ecosystem that is not limited to a single economic sector [37].

For all these reasons, higher education institutions should not disregard this reality, since training in digital entrepreneurship is a necessity that each student needs to cope with their everyday life and progress [38]. Not only must university institutions offer counselling to young entrepreneurs, but they also need to provide them with training plans by means of which the competencies necessary to deal with the challenges of digital entrepreneurship can be developed. This necessity is highlighted by the authors of [39], who state that students lack the key competencies in the field of entrepreneurship.

Following the review of different works on the subject of digital entrepreneurship [32,33,40,41], we understand this concept as the capacities, knowledge, skills and attitudes that contribute to promoting the development of creative ideas and that support the planning and management of innovative projects developed in the virtual world, and that demand the use of digital technologies. Therefore, the capacity for innovation and management that defines entrepreneurship is paired with dexterity in the use of digital technologies. This initiative itself is promoted in connection to the virtual world.

In the present article we introduce a model for the competence in digital entrepreneurship, a model that has been elaborated by means of a qualitative methodology and that has implied the inception of the ANONYMOUS project. For the construction of this model, the dimensions, competencies and indicators that make it possible to further define measurement instruments and criteria for the training of university students were defined.

\section{Methodology}

The project ANONYMOUS aims to analyze entrepreneurship competence following the construction of a model that can be applicable to a variety of environments, but especially in the context of university education. The point of departure, as we have signaled, is the definition and objectification of a model of digital entrepreneurship. Based on this model, in future phases of the research a questionnaire will be designed and validated in order to evaluate the digital entrepreneurship competence in university students, and the good practices of digital entrepreneurship will be analyzed by means of interviews with digital entrepreneurs. With all these results, we will be able to carry out, in the final phase of the project, a training proposal of digital entrepreneurship aimed at university students.

\subsection{Research Questions and Objectives}

Our research questions were: Is it possible to design a model of digital entrepreneurship? Can we find connections between European models of entrepreneurship and digital competence? In this initial phase, the main objective is the elaboration of the model of digital entrepreneurship, which needs to accommodate specific tasks to tackle throughout the subsequent phases. Our specific objectives were:

1. Performing a comparative study of the EntreComp and DigComp models, analyzing their interconnections regarding their dimensions, competences and competency indicators; 
2. Designing a model of digital entrepreneurship applicable to the training of university students;

3. Validating the model and its indicators.

\subsection{Method}

A qualitative methodology based on an interpretative approach [42] was utilized, and diverse techniques were gradually applied in order to refine the design of the model, as Reference [43] recommends. This was an inductive process. First, a technique of comparative documentary analysis was utilized (phase 1). A focus-group technique was implemented (in phases 2 and 4). Expert judgement based on the Delphi method was also utilized (phase 3). The profile of expertise was experience in education and experience in competence analysis. All experts in this study were university researchers.

\subsection{Phases and Procedure}

\subsubsection{Phase 1: Documentary Analysis}

Firstly, based on the techniques of documentary analysis [44], a work team consisting of seven researchers was in charge of performing a documentary review and criteria analysis to establish the most significant relationships between the mentioned European models (EntreComp and DigComp). For this, a double entry table where the different competences that both models lay out was utilized. Said instrument was composed of the 5 areas of the DigComp model and its 21 competences, as well as the 3 areas of the EntreComp model and its 15 competences. Each researcher performed their own analysis individually to identify which competences should be interrelated to define a model of digital entrepreneurship.

\subsubsection{Phase 2: Focus Group}

Once this task was completed, each researcher's instruments were compared, and a total of 202 relationships were found. These were analyzed in a focus-group session [45]. In this group session, the dimensions where agreements between at least 4 researchers could be observed were analyzed. As a result of this phase, 46 interconnections between both models were obtained, which implied a significant reduction in comparison to the result obtained in the previous analysis. After a re-elaboration of the work documents was completed, a second focus-group session was carried out in order to analyze the result, both regarding the content as well as the wording and objectification of the dimensions, sub-competencies and indicators.

\subsubsection{Phase 3: Expert Judgement}

Using the expert judgement technique, an external board of 8 professionals-both in digital competence and in entrepreneurship-took part in the analysis of the model, applying a two-round Delphi method [46], using which they had to select and accept or reject the suggested indicators in relation to each dimension and sub-competence.

\subsubsection{Phase 4: Final Focus Group}

In order to analyze the results obtained from the expert judgement, the focus-group technique was again utilized - on this occasion, in a single session with the participation of five researchers of the project and two external experts who had not participated in any of the previous phases. This way, the final version of the EmDigital model outlined in Section 4 was incepted.

In Figure 1, by way of a graphic summary, the different phases with their most significant research tasks are detailed. 


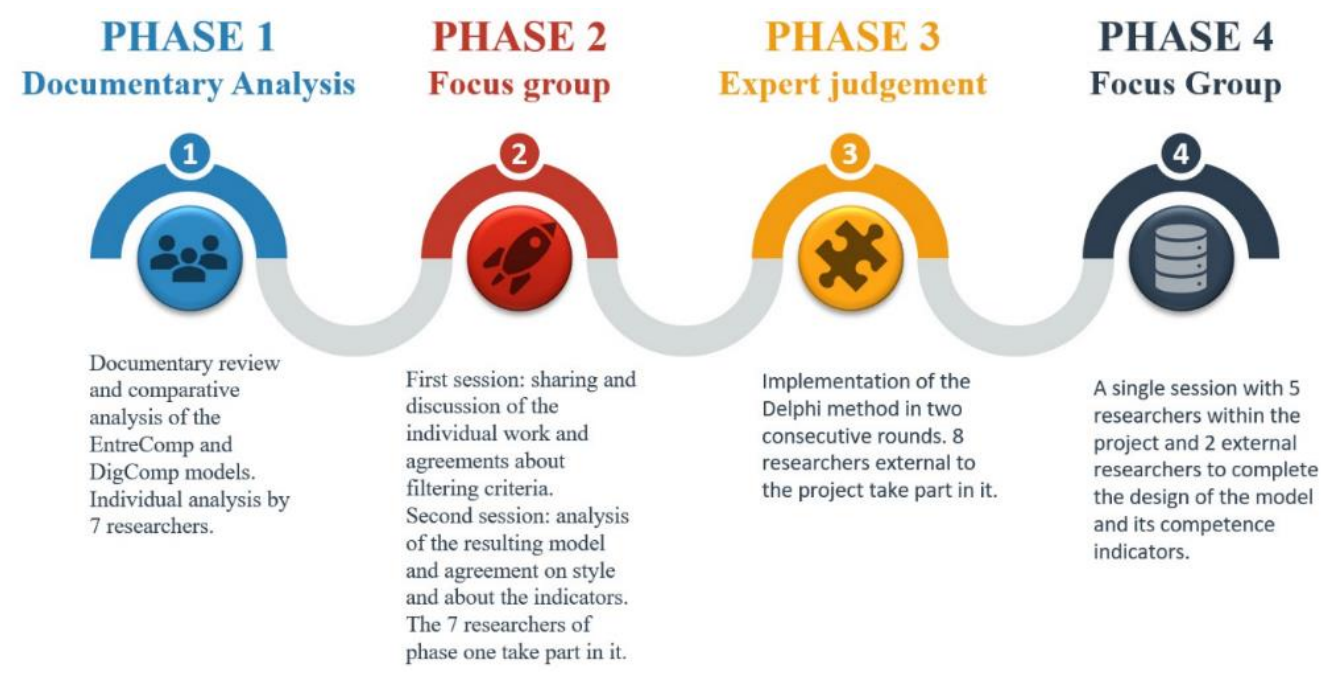

Figure 1. Phases and procedures in the design process of the EmDigital model.

\section{Results}

The EmDigital model is organized into four dimensions, which include the different competencies and indicators. In Table 1 the dimensions and their relation with the areas belonging to the reference models are described, that is, the connections between the areas of competence of the EntreComp model [2,5] and the DigComp model $[15,16]$. In these tables, we use color coding to facilitate their visibility and help to identify the areas of competence of the EmDigital model.

Table 1. Dimensions of the EmDigital model from EntreComp and DigComp models.

\begin{tabular}{cccc}
\hline $\begin{array}{c}\text { EmDigital } \\
\text { Dimensions }\end{array}$ & $\begin{array}{c}\text { EntreComp } \\
\text { Areas }\end{array}$ & $\begin{array}{c}\text { DigComp } \\
\text { Areas }\end{array}$ & $\begin{array}{c}\text { Description of the } \\
\text { EmDigital Dimensions }\end{array}$ \\
\hline $\begin{array}{c}\text { 1. Identification } \\
\text { of opportunities }\end{array}$ & A1 & A1 & $\begin{array}{c}\text { Initial process of selection and organization of the first lines } \\
\text { of action based on certain criteria. }\end{array}$ \\
$\begin{array}{c}\text { 2. Action planning } \\
\begin{array}{c}\text { 3. Initiative and } \\
\text { collaboration }\end{array}\end{array}$ & A1 and A2 & A2 and A3 & $\begin{array}{c}\text { Phase of digital design and definition of the roles involved } \\
\text { in the entrepreneurial initiative. }\end{array}$ \\
$\begin{array}{c}\text { 4. Management } \\
\text { and safety }\end{array}$ & A1, A2 and A3 & A4 and A5 & $\begin{array}{c}\text { Participation of the agents involved in the digital } \\
\text { undertaking of the original idea and favoring its progress. } \\
\text { Continuous cycle of revision and formulation of proposals, } \\
\text { based on the results obtained throughout the progress of the } \\
\text { initiative, as well as safety and problem-solving guarantees. }\end{array}$ \\
\hline
\end{tabular}

Each dimension encompasses a different number of sub-competences, according to the relationships found between the competences of the EntreComp and DigComp 2.1 models. For the formulation of the different sub-competences that make up the EmDigital model, not only were said intersections taken into account but also the literature related to entrepreneurship. We namely incorporated the concepts of learning through experience, the use of portable devices and the capacity of engaging and mobilizing others, borrowed from [47]; leadership and problem solving [48] and innovation and risk-taking, from [49]. This way, a greater accuracy is guaranteed, since other capacities or sub-competences not included in the EntreComp model or that had been approached through a different outlook are considered. The goal of this research was to endow the model with a significant consistency regarding entrepreneurship, thus being able to include in it the areas related to digital competence.

Once the relationships between the reference models were filtered and complemented with other contributions of the entrepreneurship literature, the wording and distribution of competences based on the dimensions of the EmDigital model (Table 2) were carried out. 
Table 2. Description of the competences and sub-competences of the EmDigital model.

\begin{tabular}{|c|c|c|}
\hline Dimension & Sub-Competence & Description \\
\hline \multirow{3}{*}{ 1. Identification of opportunities } & $\begin{array}{l}\text { C1. Search for and } \\
\text { analysis of information }\end{array}$ & $\begin{array}{c}\text { Research and selection of ideas as a point of departure } \\
\text { for the creation of an opportunity or } \\
\text { entrepreneurial endeavor. }\end{array}$ \\
\hline & $\begin{array}{l}\text { C2. Creativity and } \\
\text { innovation }\end{array}$ & $\begin{array}{c}\text { Identification of the potential innovative values, which } \\
\text { can be applied to the entrepreneurial initiative and } \\
\text { concretion of creative ideas to tackle } \\
\text { current challenges. }\end{array}$ \\
\hline & C3. Prospecting & $\begin{array}{l}\text { Exploring the real opportunities of the process of } \\
\text { development and implementation of ideas in the } \\
\text { immediate future. }\end{array}$ \\
\hline \multirow{3}{*}{ 2. Action planning } & C4. Success orientation & $\begin{array}{l}\text { Individual and collective efforts to transform the } \\
\text { original idea into a reality in the best possible manner. }\end{array}$ \\
\hline & C5. Leadership & $\begin{array}{l}\text { Capacity to engage and mobilize the work group and } \\
\text { influence exerted upon it to set further actions. } \\
\text { Promoting the necessary initiatives to optimize the } \\
\text { attainment of the objectives established. }\end{array}$ \\
\hline & $\begin{array}{l}\text { C6. Planning and } \\
\text { management of } \\
\text { digital identity }\end{array}$ & $\begin{array}{c}\text { Clear and understandable definition of the digital } \\
\text { identity and the different digital sub-identities } \\
\text { included in it that project any proposal of } \\
\text { digital entrepreneurship. }\end{array}$ \\
\hline \multirow{5}{*}{ 3. Initiative and collaboration } & C7. Initiative & $\begin{array}{l}\text { Carrying out of the process by which an individual } \\
\text { finds the motivations and necessary support to start } \\
\text { creating value. }\end{array}$ \\
\hline & $\begin{array}{l}\text { C8. Communication } \\
\text { and collaboration }\end{array}$ & $\begin{array}{l}\text { Interaction and formal and informal discussion in } \\
\text { open or private digital spaces on specific issues and } \\
\text { related to the action undertaken. }\end{array}$ \\
\hline & & Development of the digital content related to the \\
\hline & C9. Creation of digital value & $\begin{array}{l}\text { initiative, for its further sharing with society or the } \\
\text { community or the corresponding actors. }\end{array}$ \\
\hline & $\begin{array}{l}\text { C10. Responsibility and } \\
\text { commitment }\end{array}$ & $\begin{array}{l}\text { Assumption of obligations and personal and ethical } \\
\text { involvement (like the use of copyright and licenses) } \\
\text { acquired throughout the process of inception and } \\
\text { development of an idea, which can generate value. }\end{array}$ \\
\hline \multirow{4}{*}{ 4. Management and safety } & C11. Learning from experience & $\begin{array}{l}\text { Evaluation of the different actions implemented to } \\
\text { optimize the processes and enhance the } \\
\text { accomplishment of the objectives. } \\
\text { Intervention or mediation when solving technical, } \\
\text { communication, management or other type } \\
\text { of problems. }\end{array}$ \\
\hline & $\begin{array}{l}\text { C13. Planning and } \\
\text { organization }\end{array}$ & $\begin{array}{l}\text { Appraisal of the degree of accomplishment of the } \\
\text { objectives set and classification of stored information. }\end{array}$ \\
\hline & $\begin{array}{l}\text { C14. Techno-ethical } \\
\text { approach }\end{array}$ & $\begin{array}{l}\text { Minimization of the potential risks that the design } \\
\text { and/or implementation of the proposal could entail } \\
\text { and commitment to regular updating. }\end{array}$ \\
\hline & $\begin{array}{l}\text { C15. Motivation and } \\
\text { perseverance }\end{array}$ & $\begin{array}{l}\text { Crafting an individualized and transferable sense of } \\
\text { commitment to ensure the progress of the initiative. }\end{array}$ \\
\hline
\end{tabular}

In general terms, the EmDigital model is composed of a total of 15 competences, distributed as follows: dimension 1 of identification of opportunities (three sub-competences); dimension 2 on action planning (three sub-competences); dimension 3 of implementation and collaboration (four sub-competences); and finally, dimension 4, related to management and safety (five sub-competences).

With the aim of favoring the practical realization of the EmDigital model, each one of the 15 sub-competencies described is summed up with different indicators, as in the reference models (EntreComp and DigComp). In Table 3 we can see that dimension 1 is defined by means of 6 indicators, dimension 2 through 11 indicators, dimension 3 , through 
12 indicators and, finally, dimension 4, with 16 indicators. A total of 45 indicators form the EmDigital model.

Table 3. Indicators of the EmDigital model.

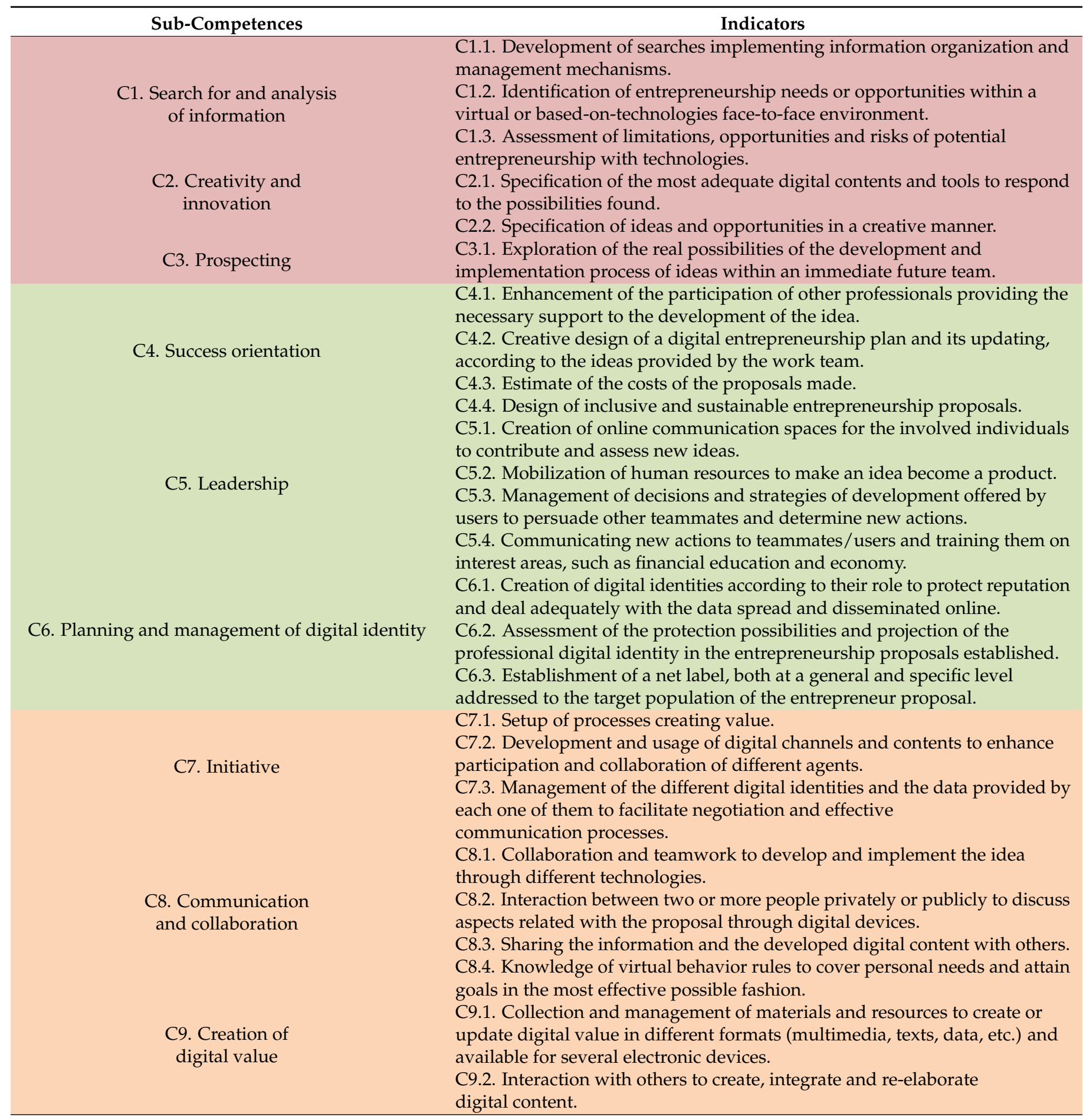


Table 3. Cont.

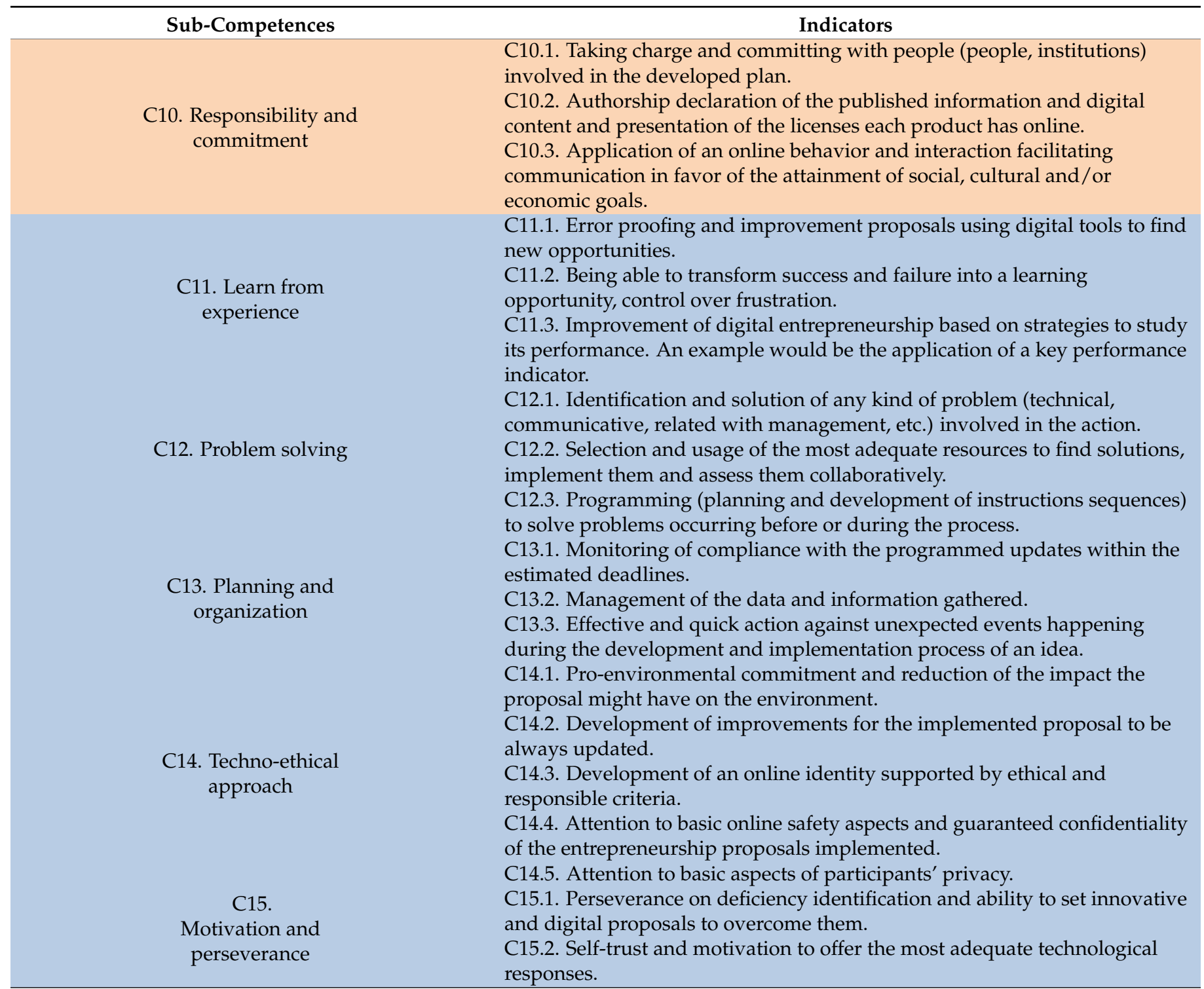

In the EntreComp and DigComp models, the areas of competence do not establish logical relationships between each other; these are analyzed separately. However, in our EmDigital model, the dimensions are presented in a sequential and gradual manner. This means that each of the dimensions describes the competences needed in each of the different phases that could be developed in an actual initiative of digital entrepreneurship. It can therefore be useful as an orientation to understand how the areas of competence are being displayed in the process of implementation of an entrepreneurial initiative, from the initial phase of generation of ideas and identification of opportunities, through the intermediate phases of planning and implementation, to the phase of analyzing the most complex elements of management and safety. With the purpose of contributing to the understanding of the model, we represented it graphically, as shown in Figure 2. In the diagram the dimensions and competences of the EmDigital model can be observed. Likewise, in the project's website ANONYMOUS, a dynamic version of the diagram, also featuring the different indicators, can be consulted. 


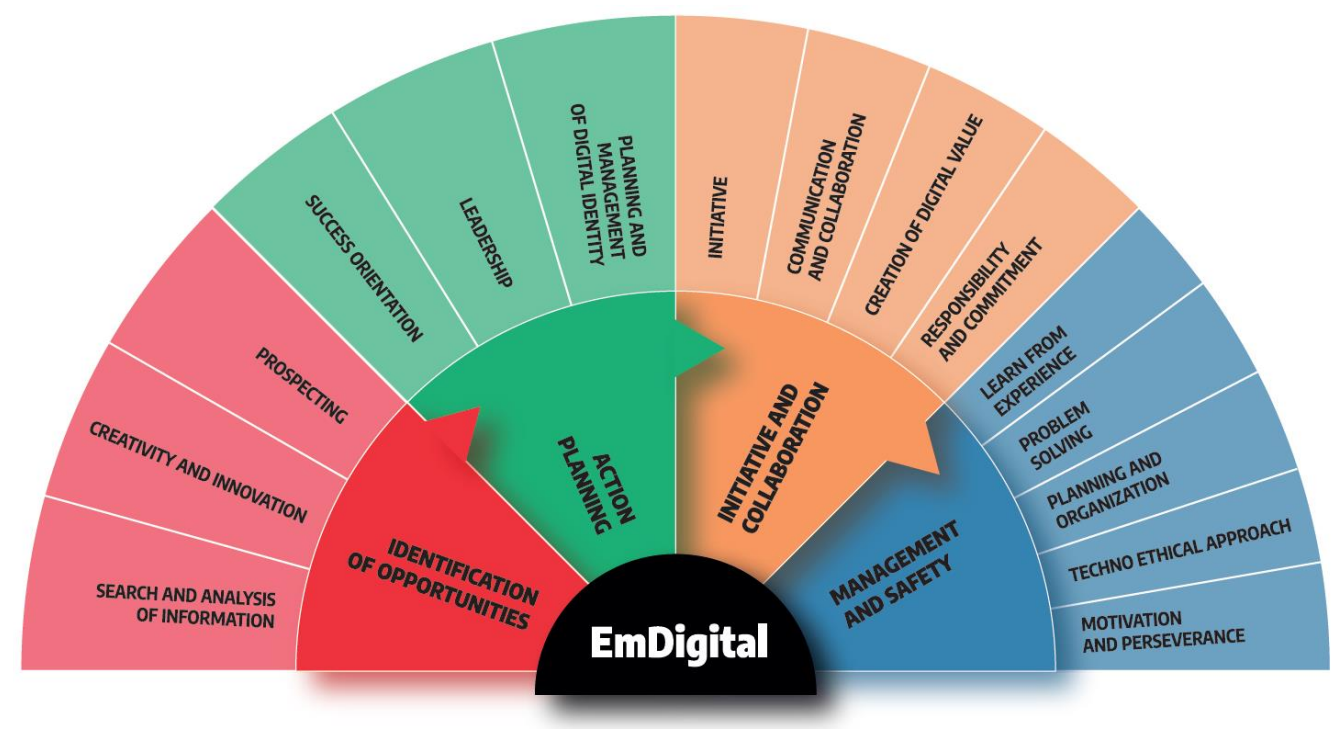

Figure 2. Diagram of the EmDigital model (dimensions and sub-competences).

\section{Discussion}

\subsection{Discussion: EmDigital Model}

The main objective that the EmDigital model of digital entrepreneurship pursues is that of specifying the theoretical bases that will allow us to elaborate digital entrepreneurship competence with university students, irrespective of their field of knowledge. We also intend to formulate institutional proposals, since effective training in digital entrepreneurship is a transversal challenge for any university degree [36,38].

In the present work, one of the tasks of the initial phase of the project is detailed. This consists of the design of a digital entrepreneurship model, which establishes the different dimensions, competencies and indicators that facilitate the realization of any entrepreneurial idea, regardless of its funding, objectives, field or any other variables that make it unique and viable.

The rigorous and systematic design process has made it possible to reveal the most significant relationships between the EntreComp and DigComp models so as to obtain a hybrid model with sufficient validity assurance. The bibliographic review was also greatly useful in the completion of the formulation of the model.

The structure of the EmDigital model is not vastly different from its reference models, as the EntreComp model is composed of 3 areas and 15 competences, the DigComp model is supported by 5 areas and 21 competences while the digital entrepreneurship model is supported by 4 dimensions and 15 competences. Furthermore, taking into account the 3 descriptors of each competence of the EntreComp model, it was also considered convenient for the EmDigital model to specify each one of its competences, adding up to a total of 45 indicators.

Unlike the previous models of entrepreneurship and digital competency, our EmDigital model has a sequential characteristic, thanks to which its understanding as well as the implementation of any entrepreneurial initiative are fostered. This characteristic makes the model useful as a research and analytical work base but also as a support for the design and implementation of initiatives in the field of digital entrepreneurship. In addition to this sequential nature of the EmDigital model, it is worth considering that not only does digital entrepreneurship present an employment opportunity full of benefits, but it also entails different risks that need to be taken into account to guarantee the durability of the entrepreneurial endeavor, as noted by Reference [50]. However, due to the sequential nature of the EmDigital model and the descriptors of competences such as "learning through experience" or "motivation and consistency", the undertaken initiative will always remain updated, and the potential risks will always be reduced to a minimum, or at least be solved in time. In short, this is a theoretical model, but we believe that it has a relevant dimension 
of applicability in practice when designing, planning and managing an entrepreneurial initiative in the virtual world.

On the other hand, it is worth highlighting that the model presented responds to the challenge posed by the authors of [37] about generating a new ecosystem in which entrepreneurship and technology converge, with the aim of addressing the present and future challenges that our society requires to progress, as we have indeed combined all the components of entrepreneurship, together with the aspects that characterize the digital competence associated with the use of technologies. Reference [32] also draws attention to the reality posed by the changes that digitalization has entailed for the business world, which endows our model with an added value, as this is an aspect for which comprehensive references (including competency indicators), as is the case for EmDigital, are lacking.

The author of [51] analyzes the impact of digitalization in the business world and leads to the conclusion about the necessity of formulating a new theoretical model for entrepreneurship, as we carried out in this research, even though in our case it was done from an educational and not a business perspective.

Hence, we understand that the EmDigital model fulfills the need to theorize about digital entrepreneurship and offers a theoretical framework for research, as well as a practical action framework for the training of university students. This way, the counselling that the competent bodies in each university (offices, clubs or other organs of university entrepreneurship) provide and the basic conceptual training-which is necessary, but insufficient to launch the entrepreneurial endeavor-are complemented [39].

\subsection{Discussion: The Relation between EmDigital Model and Open Innovation}

At a time like the present, in which technology is a key element in sociocultural evolution and business development, it is necessary to consider what an entrepreneur needs to know in order to develop and succeed in a digital context. Entrepreneurship today is not limited to a specific field, such as technology and business degrees. According to [52], open innovation is a strategy that can promote the success of any start-up. Our model could therefore be a good support for such a strategy because we have a complete collection and description of the main competences of digital entrepreneurs.

Start-ups and spin-offs have highlighted the need to promote entrepreneurial initiatives in which the interdisciplinary nature of the team, collaboration and communication are together the key to success. It is not in vain that the paradigm of open innovation, characterized and coined by Reference [53], draws attention to the fact that business and product ideas do not originate and develop within the company, so it is essential to establish links and relationships with external agents, professionals, suppliers and consumers to improve the effectiveness and efficiency of the company. In this new paradigm, therefore, the key role that technologies can play should not be overlooked, and it is perhaps for this reason that "Open innovation has achieved a certain degree of face validity within at least a small portion of high-tech industries" ([54], p. 1). In this sense, ref. [55] point out the cooperation that exists between public and private entities to favor an optimal design and development of the most avant-garde innovations in our society.

All these ideas fit perfectly with the open virtual world, so they are in line with the concept of digital entrepreneurship. If we understand that open innovation must incorporate all the potential of external knowledge in our business or project, we can agree that digital technologies are providing an incredible amount of innovative knowledge. We were able to bring together digital competences plus entrepreneurial competences to design a model that will help us to understand the possibilities of digital technologies with regard to the world of open innovation and entrepreneurship.

We studied digital entrepreneurship from a scientific point of view, and EmDigital is a validated model, so different opportunities related to open innovation should be highlighted. First, companies demand policies to improve the innovation of their services, with the intention of adjusting to new market demands. Therefore, in recent years there has been a positive trend towards university-industry-government collaboration with 
the aim of improving innovation in the business environment [56], which is fully related to EmDigital because one of the aims of this research project is to generate institutional proposals, from a training perspective, for digital entrepreneurship.

Focusing on the company-university binomial, the authors of [57] (p. 9) point out some of the benefits that this relationship can offer "to deepen the integration of production, teaching, and research; improve the efficiency of scientific research transformation; and use this part of the income to supplement school funding". However, EmDigital is not only a model to improve the initial digital entrepreneurship training of university graduates [43] but also an opportunity to improve the innovation process of companies by reflecting on what it means to be a successful entrepreneur. In this sense, we consider that the EmDigital model can be a breakthrough opportunity for any type of entrepreneurship: the entrepreneurship of novice entrepreneurs, the intra-entrepreneurship of employees and organizational entrepreneurship [58].

In conclusion, this model is aimed at university students who are going to start their working life, but future research can use this model to evaluate competences of workers and to design processes to improve their digital entrepreneurship. For all that has been described, EmDigital is an opportunity to improve the development of open innovation, as according to [59], through university research it is possible to promote the establishment of new innovation ecosystems, giving rise to knowledge-based enterprises. More specifically, EmDigital could mean the creation of an open innovation community (OIC) to achieve the knowledge transfer that is so demanded in these open innovation processes [60].

\section{Conclusions}

Echoing a prospective vision based on the present work, it is worth highlighting that another research task that is being carried out is the selection of good practices of digital entrepreneurship, according to previously defined criteria, supported both in the EmDigital model as well as in the visual tool known as the strategic tree, which consists of facilitating the strategic reflection in entrepreneurs in regard to the management of their proposal [61]. Likewise, different interviews with successful digital entrepreneurs are being conducted with a double objective: concretizing, if need be, the indicators of the EmDigital model and promoting the design of the training proposal in digital entrepreneurship for university students from a practical perspective.

In this work, an innovative model of digital entrepreneurship to guarantee the sustainability of an entrepreneurial project is offered, thus generating a positive impact for the accomplishment of the objectives of sustainable development promoted by the United Nations. Consequently, EmDigital not only aims to tackle the educational and work challenges described in the text but also social ones.

Author Contributions: Conceptualization, P.P.-E., I.M.S.-F. and P.A.G.-T.; methodology, P.P.-E., I.M.S.-F. and P.A.G.-T.; investigation, P.P.-E., I.M.S.-F. and P.A.G.T; writing-original draft preparation, P.P.-E., I.M.S.-F. and P.A.G.-T.; writing-review and editing, P.P.-E., I.M.S.-F. and P.A.G.-T.; project administration, P.P.-E.; funding acquisition, P.P.-E. All authors have read and agreed to the published version of the manuscript.

Funding: This research was funded by the Séneca-Science and Technology Agency of the Region of Murcia (Spain), grant number REF.20962/PI/18. The project is running by Paz Prendes Espinosa (University of Murcia).

Acknowledgments: The authors are grateful to the research team and the experts who have participated in this project.

Conflicts of Interest: The authors declare no conflict of interest. The funders had no role in the design of the study; in the collection, analyses or interpretation of data; in the writing of the manuscript or in the decision to publish the results. 


\section{References}

1. Aznar, P.; Martínez-Agut, M.P. El emprendimiento y sostenibilidad: El emprendimiento sostenible. In Cultura Emprendedora y Educación, 1st ed.; Núñez, L., Ed.; University of Sevilla: Sevilla, Spain, 2015; pp. 143-151.

2. McCallum, E.; Weich, R.; McMullan, L.; Price, A. Get Inspired Make Happen into Action EntreComp. A User Guide to the European Entrepreneurship Competence Framework. 2018. Available online: https:/ / bit.ly/3fV2FY5 (accessed on 12 November 2020).

3. Jones, B.; Iredale, N. Viewpoing: Enterpirse Education as Pedagogy. Educ. Train. 2010, 52, 7-18. [CrossRef]

4. European Commission/EACEA/Eurydice. The Structure of the European Education Systems 2016/17: Schematic Diagrams. 2016. Available online: https:/ / bit.ly/34IvPF9 (accessed on 12 November 2020).

5. Bacigalupo, M.; Kampylis, P.; Punie, Y.; Van Den Brande, G. EntreComp: The Entrepreneurship. Competence Framework. 2016. Available online: https:/ / bit.ly /2z9PlhJ (accessed on 12 November 2020).

6. Segarra, M.; Grangel, R.; Belmonte, O.; Aguado, S. Cómo potenciar el emprendimiento y la innovación mediante el desarrollo de proyectos de base tecnológica en el contexto docente universitario. Rev. Tecnol. Cienc. Educ. 2017, 6, 11-33. Available online: http:/ / bit.ly/2JvBVP3 (accessed on 12 February 2021).

7. Esther, F.; González, J.; Sánchez, P.; Sanmartin, J. Emprendimiento e Innovación: Agentes Potenciadores de la Empresa Familiar. Sapientiae 2019, 4, 247-265. Available online: http:/ / bit.ly/3b0qdri (accessed on 12 February 2021).

8. Torres, F.; Briones, X.F. Innovación y emprendimiento en la sostenibilidad del desarrollo económico local. Sapientiae 2019, 4, 294-305. [CrossRef]

9. Torres-Coronas, T.; Vidal-Blasco, M.A.; Arias-Oliva, M. E-emprendimiento en la Educación Superior: La competencia digital. Rev. Iberoam. Educ. 2014, 64, 1-12. [CrossRef]

10. He, T.; Li, S. A comparative study of digital informal learning: The effects of digital competence and technology expectancy. Br. J. Educ. Technol. 2019, 50, 1744-1758. [CrossRef]

11. Prendes, M.P.; Román, M.; González, V. Modelo integral de Análisis de la Competencia Digital en las Instituciones de Enseñanza Superior: Profesorado y Estudiantes en el Contexto Organizativo. Rev. Panor. 2021, 32, 12-31. Available online: https: / / bit.ly/3ntK0GD (accessed on 12 February 2021).

12. European Commission. Recommendation of the European Parliament and of the council of 18 December 2006. Off. J. Eur. Union 2006, 394. Available online: https:/ / bit.ly /2UqSf93 (accessed on 12 February 2021).

13. Durán, M.; Gutiérrez, I.; Prendes, M.P. Certificación de la competencia TIC del profesorado universitario: Diseño y validación de un instrumento. Rev. Mex. Investig. Educ. 2016, 21, 527-556. Available online: http://bit.ly/2YHys7e (accessed on 12 February 2021).

14. Prendes, M.P.; Gutiérrez, I.; Martínez, F. Competencia digital: Una necesidad del profesorado universitario en el siglo XXI. RED 2018, 56. [CrossRef]

15. Carretero, S.; Vourikani, R.; Punie, Y. DigComp 2.1. The Digital Competence Framework for Citizens with Eight Proficiency Levels and Examples of Use. 2018. Available online: https:/ / bit.ly/3dYdA1q (accessed on 12 November 2020).

16. Kluzer, S.; Pujol, S. DigComp into Action. Get Inspired Make it happen. A User Guide to the European Digital Competence Framework. 2018. Available online: https:/ / bit.ly/3e0I9Ub (accessed on 12 November 2020).

17. Pardo-García, C.; Barac, M. Promoting employability in higher education: A case study on boosting entrepreneurship skills. Sustainability 2020, 12, 4004. [CrossRef]

18. Tovar, E.; Tabuenca, B.; Piedra, N. EntreCom4ALL MODEL to sustain the entrepreneurship competence needs. In Proceedings of the IEEE Global Engineering Education Conference, Porto, Portugal, 27-30 April 2020; pp. 1937-1940.

19. Baena-Luna, P.; García-Río, E.; Monge-Agüero, M. Entrecomp: Marco competencial para el emprendimiento. Una revisión sistemática de la literatura sobre su uso y aplicación. Inf. Tecnol. 2020, 31, 163-172. [CrossRef]

20. Paños-Castro, J.; Arruti, A. Y tú: ¿eres teacherpreneur? Validación y Aplicación de un Cuestionario Para Medir la Autopercepción y el Comportamiento Emprendedor en Profesores Universitarios del Grado en Educación Primaria. Profesorado $2019,23$. Available online: https:/ / bit.ly/33DFPjp (accessed on 12 February 2021). [CrossRef]

21. Sáenz-Bilbao, N.; López-Vélez, A.L. Las competencias de emprendimiento social, COEMS: Aproximación a través de programas de formación universitaria en Iberoamérica. REVESCO Rev. Estud. Corp. 2015, 119, 159-182. [CrossRef]

22. Durán, M.; Prendes, M.P.; Gutiérrez, I. Certificación de la Competencia Digital Docente: Propuesta para el profesorado universitario. RIED 2019, 22, 187-205. [CrossRef]

23. Zeehan, F.; Alias, R.A.; Tasir, Z. Mapping the attribute of digital competency framework for educators. Int. J. Psychosoc. Rehabil. 2020, 24, 2361-2371.

24. Flores-Lueg, C.B.; Roig, R. Diseño y validación de una escala de autoevaluación de competencias digitales para estudiantes de Pedagogía. Píxel-Bit 2016, 48, 209-224. [CrossRef]

25. González, V.; Román, M.; Prendes, M.P. Formación en competencias digitales para estudiantes universitarios basada en el modelo DigComp. Edutec 2018, 65, 1-15. [CrossRef]

26. Gutiérrez, I.; Serrano, J.L. Evaluation and development of digital competence in future primary school teachers at the University of Murcia. NAER 2016, 5, 51-56. [CrossRef]

27. Reisoglu, I.; Cebi, A. How can the digital competences of pre-service teachers be developed? Examining a case study through the lens of DigComp and DigCompEdu. Comput. Educ. 2020, 156, 1-16. [CrossRef] 
28. Gisbert, M.; Espuny, C.; González, J. INCOTIC. Una herramienta para la @utoevaluación diagnóstica de la competencia digital en la universidad. Profesorado 2011, 15, 76-89. Available online: https:/ / bit.ly/3iBRZ0n (accessed on 12 February 2021).

29. Ruiz-Cabezas, A.; Medina, M.C.; Pérez, E.; Medina, A. University teachers' training: The Digital Competence. Píxel-Bit 2020, 58, 181-215. [CrossRef]

30. Lorenzo, O. La empresa en Red: Emprendimiento+innovación+Tecnología. Boletín Estud. Económicos 2012, 67, 133-144.

31. Omar, F.I.; Othman, N.A.; Hassan, N.A. Digital inclusion of ICT and its implication among entrepreneurs of small and médium enterprises. Int. J. Eng. Adv. Technol. 2019, 8, 747-752. [CrossRef]

32. Allen, J. Digital Entrepreneurship, 1st ed.; Routledge: London, UK, 2019; pp. 1-260.

33. Giones, F.; Brem, A. Digital technology entrepreneurship: A definition and research agenda. Technol. Innov. Manag. Rev. 2017, 7, 44-51. Available online: https:/ / bit.ly/38D11LS (accessed on 12 February 2021). [CrossRef]

34. Mababu, R. La transformación digital y el emprendimiento de los jóvenes en Iberoamérica. Rev. Int. Comp. Relac. Labor. Derecho Empl. 2017, 5, 111-128. Available online: http:/ / bit.ly/2Pwp7fd (accessed on 12 February 2021).

35. Moysidou, K.; Hausberg, J.P. In crowdfunding we trust: A trust-building model in lending crowdfunding. J. Small Bus. Manag. 2020, 58, 511-543. [CrossRef]

36. López-Navarrete, A.J.; López-Cepeda, I.; álvarez-Ruiz, A. The "Hawkers" case study: A model of the strategic use of resources offered by digital environments. Mediterr. J. Commun. 2019, 10, 45-61. [CrossRef]

37. Zubillaga, A.J.; Ardanza, N. Emprendimiento digital en Euskadi: Innovación abierta para la competitividad empresarial. Orkestra 2018, 42. Available online: https: / / bit.ly/3bM66gi (accessed on 12 February 2021).

38. Ratten, V.; Usmanji, P. Entrepreneurship education: Time for a change in research direction? Int. J. Manag. Educ. 2020, 100367. [CrossRef]

39. Hennemann, S.; Liefner, I. Employability of German geography graduates: The mismatch between knowledge acquired and competences required. J. Geogr. High. Educ. 2010, 34, 215-230. [CrossRef]

40. Basly, S.; Hammouda, A. Family businesses and digital entrepreneurship adoption: A conceptual model. J. Entrepeneurship 2020, 29, 326-364. [CrossRef]

41. Bican, P.M.; Brem, A. Digital Business Model, Digital Transformation, Digital Entrepreneurship: Is there a sustainable "digital"? Sustainability 2020, 12, 5239. [CrossRef]

42. Silverman, D. Qualitative Research, 4th ed.; Sage: London, UK, 2016; pp. 1-480.

43. Vargas-Larraguivel, P.A.; Liévano-Morales, J.; Calderón-Martínez, G. Factores de impacto en la formación emprendedora en estudios de educación superior. Caso CETYS Universidad. Rev. Incl. 2021, 8, 198-215. Available online: https://bit.ly/3rBtTrN (accessed on 12 February 2021).

44. Sánchez-Díaz, M.; Vega-Valdés, J.C. Algunos aspectos teórico-conceptuales sobre el análisis documental y el análisis de información. Cienc. Inf. 2003, 34, 49-60. Available online: https:/ / bit.ly /3izggo1 (accessed on 12 February 2021).

45. Hernández-Sampieri, R.; Fernández-Collado, C.; Baptista-Lucio, M.P. Metodología de la Investigación, 5th ed.; McGrall-Hill Educación: Ciudad de México, México, 2010; pp. 1-656.

46. Reguant, M.; Torado, M. El método Delphi. REIRE 2016, 9, 87-102. Available online: http://bit.ly/2Ixj3P6 (accessed on 12 February 2021).

47. Prendes, M.P.; Solano, I.M.; González, J.; Cerdán, F. Competencia de emprendimiento en Educación Secundaria: Percepción del profesorado sobre el estado actual y las posibilidades futuras en el contexto europeo. Bordón 2020, 72, 153-172. [CrossRef]

48. Athayde, R. Measuring Potential in Young People. Entrepreneurship. Theory Pract. 2009, 33, 481-500. [CrossRef]

49. Hamburg, I.; David, A. Entrepreneurship and Entrepreneurial Skils in Europe, 1st ed.; Barbara Budrich Publishers: Leverkusen, Germany, 2017; pp. 1-116.

50. Shalu, S.; Archana, V. The digital revolution: Entrepreneurial threats \& prospects. Int. J. Acad. Res. Dev. 2018, 3, 1059-1060. Available online: https:/ / bit.ly/3lo8f7k (accessed on 12 February 2021).

51. Nambisan, S. Digital entrepreneurship: Toward a digital technology perspective of entrepreneurship. Entrep. Theory Pract. 2016, 414, 1-27. [CrossRef]

52. Mastrostefano, K.; Morales-Alonso, G.; Greco, M.; Grimaldi, M.; Blanco-Serrano, J.A. The importancia for a start-up to trust in open innovation: A systematic literature review. Econ. Bus. Lett. 2020, 9, 289-297. [CrossRef]

53. Chesbrough, H. Open Innovation: The New Imperative for Creating and Profiting from Technology; Harvard Business School Press: Boston, MA, USA, 2003.

54. Chesbrough, H. Managing Open Innovation. Res. Technol. Manag. 2004, 7, 23-26. [CrossRef]

55. Ferraris, A.; Santoro, G.; Pelliceli, A.C. Openness of public governments in smart cities: Removing the barriers for innovation and entrepreneurship. Int. Entrep. Manag. J. 2020, 16, 1259-1280. [CrossRef]

56. Bertello, A.; Ferraris, A.; De Bernardi, P.; Bertoldi, B. Challenges to open innovation in traditional SMEs: An analysis of precompetitive projects in university-industry-government collaboration. Int. Entrep. Manag. J. 2021. [CrossRef]

57. Yan, H.; Wang, L.; Yan, X.; Zhai, Q. International and external coordinated open innovation ecosystems: Concept building and applying to Shanghai Zizhu international education park. J. Open Innov. Technol. Mark. Complex. 2020, 6, 113. [CrossRef]

58. Yun, J.J.; Zhao, X.; Jung, K.; Yigitcanlar, T. The culture for open innovation dynamics. Sustainability 2020, 12, 5076. [CrossRef]

59. Davies, G.H.; Flanagan, J.; Bolton, D.; Roderick, S.; Joyce, N. University knowledge spillover from an open innovation technology transfer context. Knowl. Manag. Res. Pract. 2020. [CrossRef] 
60. Vélez-Rolón, A.M.; Méndez-Pinzón, M.; Avecedo, O.L. Open innovation community for university-industry knowledge transfer: A Colombian case. J. Open Innov. Technol. Mark. Complex. 2020, 6, 181. [CrossRef]

61. Ogel, L.; Castillo, A. Árbol estratégico = strategic tree. ArDin 2012, 1, 106-130. Available online: https://bit.ly/30F5J13 (accessed on 12 February 2021). 